\title{
Gene Polymorphism of Matrix Metalloproteinase-1 in Chronic Periapical
} Lesions

\author{
Evrosimovska B*, Dimova C and Popovska M \\ Faculty of Dentistry, Saints Cyril and Methodius University of Skopje, Macedonia
}

\begin{abstract}
Background/Aim: Matrix metalloproteinases (MMPs) are zinc and calcium dependent enzymes capable of degrading almost all extracellular matrix and basement membrane components. This group of proteolytic enzymes is believed to be implicated in the breakdown of extracellular matrix in normal physiological processes, as well as playing an important role in many destructive pathological oral processes, such as periodontal tissue destruction, root caries, tumor invasion, and chronic periapical inflammation (CPL). The aim of this study was to analyze polymorphism in the gene MMP-1 and their association and influence on clinical manifestation of chronic periapical lesions in order to provide new advances regarding the involvement of MMPs in various oral diseases associated with the inflammatory process.
\end{abstract}

Materials and methods: A total of 240 unrelated Macedonian subjects were included in the present study. Polymorphism -1607 1G/2G in the gene MMP-1 detected with restriction enzymes Alul, Xmnl and polymorphism -519 $\mathrm{A} / \mathrm{G}$ in the gene MMP-1 detected with restriction enzyme $\mathrm{Kpnl}$ was studied in 120 patients with $\mathrm{CPL}$ and 120 controls without any signs of chronic or acute inflammatory process in the jaw. The amplification of the region of selected gene was made with polymerase chain reactionrestriction fragment length polymorphism (PCR-RFLP).

Results: Our results showed that there was a differences in the allele and genotype frequencies of the MMP-1 polymorphism between patients with $\mathrm{CPL}$ and controls $(p<0.05)$. Also this study suggests that MMP-1 polymorphism $-16071 \mathrm{G} / 2 \mathrm{G}$ detected with restriction enzymes $\mathrm{Alul}, \mathrm{Xmn} /$ was a risk for expression of $\mathrm{CPL}(\mathrm{OR}=18.38<4.06<\mathrm{OR}<115.46$; $\mathrm{OR}=7.73<3.1<\mathrm{OR}<19.55)$ and MMP-1 polymorphism $-519 \mathrm{~A} / \mathrm{G}$ detected with restriction enzyme $\mathrm{Kpnl}$ was a risk for expression of $\mathrm{CPL}(\mathrm{OR}=12.11<4.64<\mathrm{OR}<32.30)$.

Conclusions: Detection of this genetic polymorphism is relevant for obtaining providential treatment of patients who are at high risk of chronic periapical.

Keywords: Polymorphism; Genotype; Periapical lesions; Arteriosclerosis; Matrix metalloproteinases

\section{Introduction}

Matrix metalloproteinases (MMPs) are zinc and calcium dependent enzymes capable of degrading almost all extracellular matrix and basement membrane components [1]. This group of proteolytic enzymes believed to be implicated in the breakdown of extracellular matrix in normal physiological processes, such as embryonic development, blastocyst implantation, organ morphogenesis, nerve growth, ovulation, cervical dilatation, postpartum uterine involution, endometrial cycling, hair follicle cycling, bone remodeling, wound healing, angiogenesis, apoptosis, etc. [2].

Matrixins play a critical role in pathological processes (e.g. arthritis, cancer, cardiovascular disease, nephritis, neurological disease, breakdown of blood brain barrier, periodontal disease, skin ulceration, gastric ulcer, corneal ulceration, liver fibrosis, emphysema, fibrotic lung disease, etc. [3]. According to the important role of MMPs in inflammation [4], it has been shown that genetic variation affecting the expression of MMPs influences the susceptibility and progression of various oral diseases [5]. Matrix metalloproteinases are strongly associated with levels of inflammation and play a major role in bone remodeling and bone resorption [6].

Bone matrix is comprised mostly of mineralized fibrillar type I collagen. MMPs are capable of cleaving native, nondenatured collagens with long uninterrupted triple helices and can function as collagenases in vivo [7].

Expression of MMPs is low in normal cells, and these low levels allow for healthy connective tissue remodeling. In pathologic conditions, however, the level of MMPs expression increases considerably, resulting in aberrant connective tissue destruction. Expression of MMPs is regulated primarily at the transcriptional level where the promoter of the genes responds to different regulators [8]. Some functional polymorphisms have been described in the regulatory region of MMPs genes [5]. Because destructive enzymes of the MMPs family are involved in this process, allele polymorphisms of MMPs genes are interesting candidates for analyses of the influence, susceptibility and severity of chronic periapical lesions (CPLs).

Subfamily of human colagenases has three members, from which MMP-1 (fibroblast type of colgenase, colagenase-1) is one of our interest [9]. Gen of the MMP-1 is localized on chromosome 11q22 and its expression was shown in various types of healthy cells (stromal fibroblasts, macrophage, endothelial and epithelial cells), as well as in different inflammatory and carcinoma cells [10].

Level of expression of MMP-1 can be under the influence of different single nucleotide polymorphism in promontory region. Insertion or deletion of the guanine from the position -1607 can be identified in humans in promoter of the gen of MMP-1 developing two

*Corresponding author: Biljana Evrosimovska, Department of Oral Surgery Saints Cyril and Methodius University of Skopje, St. Mother Theresa 17, Skopje 1000, Macedonia, The Former Yugoslav Republic, Balkans, Tel: 0038975289925; E-mail: bevrosimovska@gmail.com

Received May 02, 2017; Accepted May 19, 2017; Published May 26, 2017

Citation: Evrosimovska B, Dimova C, Popovska M (2017) Gene Polymorphism of Matrix Metalloproteinase-1 in Chronic Periapical Lesions. Dentistry 7: 436. doi:10.4172/2161-1122.1000436

Copyright: () 2017 Evrosimovska B, et al. This is an open-access article distributed under the terms of the Creative Commons Attribution License, which permits unrestricted use, distribution, and reproduction in any medium, provided the original author and source are credited. 
different alleles: one has single guanine $(1 \mathrm{G})$, and the other two guanine (2G) $[11]$

Patients who carried 2G allele have predisposition to develop several types of carcinoma or their rapid progression [12] to develop arthritis [5], arteriosclerosis, periodontitisot [13], unsuccessful osteointegration of the implant [14], and coronary heart disease in patients with diabetes mellitus [15].

The aim of this study was to analyze polymorphism in the gene MMP-1 and their association and influence on clinical manifestation of chronic peripical lesions in order to provide new advances regarding the involvement of MMPs in various oral diseases associated with the inflammatory process.

\section{Patients and Method}

\section{Patients' samples}

Selection of the patients was made according to internal criteria, on the basis of sated clinical diagnosis, after detail analysis and clinical examination with analysis of X-ray changes. In this study patients who have antibiotic or immune-suppressive therapy, patients with systematic disorders and infections, patients with hypertension, patients with diabetes mellitus, women with pregnancy, menopause women and children under the age of $18^{\text {th }}$ and those patients who have clinical signs of parodontopathia were excluded.

Two groups were formed. First group was formed from 40 patients after clinically and radiographic verified chronic periapical lesion. Only the patients with clinical diagnosis Parodontitis chronica periapicalis granulomatosa seu granulom (PHPG) were included. Second (control) group formed 120 patients without endodontic treated teeth and absents of chronic periapical process or acute odontogenic infection.

From the local dental status trough clinical methods in patients with clinical diagnosis, PHPG and exhaustive clinical examination presence of subjective symptoms: pain, percussion and palpation sensitivity and objective symptoms: swelling, drainage of exudates from the root canal and presence of fistula. These dates were expressed by CPI (clinical periapical index).

From the X-ray analyses following parameters in patients with chronic periapical lesions were registered: condition of the parodontium, presence of chronic periapical lesions, determination of its limits, and presence of bone resorption.

All the teeth with chronic periapical lesions were non vital and we used vitality test for diagnostic measures. Patients with PHPG undergo the surgical procedure. Before the resection of the apex, the root canals of the teeth were filled with same material (Thymol-phosphate cement). Teeth from the upper and lower jaw and single root or teeth with two roots were examined in this study.
In the aseptic condicions, from each patient with vene-punction sample of vein blood $(10 \mathrm{ml})$ was taken in sterile epruvete (Vaccutainer $\left.{ }^{\circ}\right)$ in which was anticoagulant $\left(\mathrm{EDTA} \cdot \mathrm{Na}^{2}\right)$. Ich sample was frozen at $-80^{\circ} \mathrm{C}$ as soon as possible and stored until the analysis.

\section{DNA preparation}

Standard isolation of genomic DNA from the nuclear cells was made with natrium chlorid extraction and afterwords precipitation with ethanol [16]. Samples of DNA izolates were aliqvated in few epruvetes, from wich, one was kept from $+4^{\circ} \mathrm{C}$ till $+8^{\circ} \mathrm{C}$, and that one was used for analysis. The other EDTA tubes were kept as a reserve in the bank of samples at temperature from $-18^{\circ} \mathrm{C}$ till $-20^{\circ} \mathrm{C}$. Amplification of the regions of elected genes was made with polymerase chain reaction (PCR) and performed in PCR machine (Perkin-Elmer Gene Amp System 2400) (Table 1).

Presence or absence of some normal or mutated sequence in PCR product followed by restriction digestion results with different size of fragments. Successful amplification was verified with presence of electrophoresis marker (PCR Marker, Bio-Rad) with agrarelectrophoreze (Bio-Rad, USA). Production of digestion were vizualizate with fluoroscence painting of the gel with etidium bromid.

\section{Statistical Analysis}

Differences between two parameters in series with numeric characteristic were tested with Pearson Chi-Square test. Statistical significance shows that results with values $p<0.05$. Tests for HardyWeinberg equilibrium among groups were conducted with aim to examined presence of selective force who effect on distribution of the alleles using observed genotype frequencies and a $\chi^{2}$ test with one degree of freedom. Risk for developing chronic periapical lesion according to gene polymorphism of MMP-8 (associative or protective roll) was determinate with odd ratio (OR).

\section{Results}

Representation of the polymorphism $-16071 \mathrm{G} / 2 \mathrm{G}$ of the gene of MMP-1 detected with restricted enzyme AluI in the patients from examined groups is shown in Table 2. Statistical analysis confirm that there is a statistical significance between gene poymorphism of MMP-1 detected with restriction enzyme AluI and CPL (Pearson Chi-square: 40.9120, $\mathrm{df}=2, \mathrm{p}=0.000000$ ). Polymorphism $-16071 \mathrm{G} / 2 \mathrm{G}$ for the gene of MMP-1 detected with restictive enzyme AluI was risk factor for expression of chronic periapical lesion $(\mathrm{OR}=18.38<4.06<\mathrm{OR}<115.46)$. Representation of the polymorphism $-16071 \mathrm{G} / 2 \mathrm{G}$ of the gene of MMP1 detected with restricted enzyme XmnI in the patients from examined groups is shown in Table 3.

Statistical analysis confirm that there is a statistical significance

\begin{tabular}{|c|c|c|c|c|c|c|}
\hline Gene & $\begin{array}{l}\text { Polymor- } \\
\text { phism }\end{array}$ & Pramer & PCR conditions & $\begin{array}{l}\text { Length of PCR } \\
\text { ampli-fication }\end{array}$ & $\begin{array}{l}\text { Restri-ction } \\
\text { enzyme }\end{array}$ & $\begin{array}{c}\text { Restri-ction } \\
\text { digestion }\end{array}$ \\
\hline MMP-1 & -1607 1G/2G & $\begin{array}{c}\text { (F) 5'-TGA CTT TTA AAA CAT AGT CTA TGT TCA-3' } \\
\text { (R) 5'- TCT TGG ATT GAT TTG TTG AGA TAA GTC } \\
\text { ATA GC-3' }\end{array}$ & $\begin{array}{l}35 \text { cycles: } \\
94^{\circ} \mathrm{C} 30 \mathrm{~s} \\
54^{\circ} \mathrm{C} 30 \mathrm{~s} \\
72^{\circ} \mathrm{C} 30 \mathrm{~s}\end{array}$ & $269 \mathrm{bp}$ & Alul & $(241+28) b p$ \\
\hline MMP-1 & $-16071 \mathrm{G} / 2 \mathrm{G}$ & $\begin{array}{l}\text { (F) 5'-TCG TGA GAA TGT CTT CCC ATT-3' } \\
\text { (R) 5'-TCT TGG ATT GAT TTG AGA TAA GTC ATA-3' }\end{array}$ & $\begin{array}{l}35 \text { cycles: } 93^{\circ} \mathrm{C} 30 \mathrm{~s} \\
5^{\circ} \mathrm{C} 30 \mathrm{~s}, 72^{\circ} \mathrm{C} 30 \mathrm{~s} \\
72^{\circ} \mathrm{C} 5 \mathrm{~min}\end{array}$ & $118 \mathrm{bp}$ & Xmnl & $(29+89) \mathrm{bp}$ \\
\hline MMP-1 & $-519 \mathrm{~A} / \mathrm{G}$ & $\begin{array}{l}\text { (F) 5'-CAT GGT GCT ATC GCA ATA GGG T-3' } \\
\text { (R) 5'-TGC TAC AGG TTT CTC CAC ACA C-3' }\end{array}$ & $\begin{array}{l}30 \text { cycles: } 94^{\circ} \mathrm{C} 30 \mathrm{~s} \\
49^{\circ} \mathrm{C} 30 \mathrm{~s}, 72^{\circ} \mathrm{C} 20 \mathrm{~s} \\
72^{\circ} \mathrm{C} 4 \mathrm{~min}\end{array}$ & $200 \mathrm{bp}$ & Kpnl & $(176+24) b p$ \\
\hline
\end{tabular}

Table 1: Sequence of PCR primers with their restriction enzyme. 
between gene poymorphism of MMP-1 detected with restriction enzyme XmnI and CPL (Pearson Chi-square: 57.5222, $\mathrm{df}=2$, $\mathrm{p}=0.000000$ ). Polymorphism $-1607 \mathrm{1G} / 2 \mathrm{G}$ for the gene of MMP-1 detected with restictive enzyme $A l u \mathrm{I}$ was risk factor for expression of chronic periapical lesion $(\mathrm{OR}=7.73<3.1<\mathrm{OR}<19.55)$. Representation of the polymorphism $-519 \mathrm{~A} / \mathrm{G}$ of the gene of MMP-1 detected with restricted enzyme $K p n I$ in the patients from examined groups is shown in Table 4.

Statistical analysis confirm that there is a statistical significance between gene poymorphism of MMP-1 detected with restriction enzyme KpnI and CPL (Pearson Chi-square: 45.8285, $\mathrm{df}=2$, $\mathrm{p}=0.000000$ ). Polymorphism $-519 \mathrm{~A} / \mathrm{G}$ for the gene of MMP-1 detected with restictive enzyme $K p n I$ was risk factor for expression of chronic periapical lesion $(\mathrm{OR}=12,11<4.64<\mathrm{OR}<32.30)$ (Table 5). Detected frequence of $2 \mathrm{G}$ allel in polymorphs $-16071 \mathrm{G} / 2 \mathrm{G}$ of the gene for MMP-1 detected with restricted enzyme $X m n \mathrm{I}$ was significant higher in patients with CPL than those from the control group $(f(2 \mathrm{G})=0.18)$. With that we can confirm protective role of $1 \mathrm{G}$ allele for developing an inflammatory process. Frequency of the genotypes was $f(1 \mathrm{G} / 1 \mathrm{G})=0.2$; $f(1 G / 2 G)=0.2 ; f(2 G / 2 G)=0.6$ and $p<0.05(p=0.0002)$ witch shows that there is an equilibrium (Tables 5 and 6).
Frequency of the genotypes was $f(1 G / 1 G)=0.7 ; f(1 G / 2 G)=0.2$ $f(2 G / 2 G)=0.1$ and $p>0.05(p=0.0002)$ witch shows that there is no equilibrium (Tables 6 and 7). Detected frequence of $2 \mathrm{G}$ allel in polymorphs $-16071 \mathrm{G} / 2 \mathrm{G}$ of the gene for MMP-1 detected with restricted enzyme $A l u \mathrm{I}$ was significant higher in patients with CPL than those from the control group $(f(2 G)=0.30)$. Frequency of the genotypes was $\mathrm{f}(\mathrm{GG} / 1 \mathrm{G})=0.0 ; \mathrm{f}(1 \mathrm{G} / 2 \mathrm{G})=0.5 \mathrm{f}(2 \mathrm{G} / 2 \mathrm{G})=0.5$ and $\mathrm{p}>0.05(\mathrm{p}=0.3133)$ witch shows that there is no equilibrium (Tables 7 and 8 ).

Frequency of the genotypes was $f(1 \mathrm{G} / 1 \mathrm{G})=0.5 ; \mathrm{f}(1 \mathrm{G} / 2 \mathrm{G})=0.4$; $f(2 G / 2 G)=0.1$ and $p>0.05 \quad(p=0.8259)$ witch shows that there is no equilibrium (Tables 8 and 9).Detected frequence of $2 \mathrm{G}$ allel in polymorphs $-519 \mathrm{~A} / \mathrm{G}$ of the gene for MMP-1 detected with restricted enzyme KpnI was significant higher in patients with CPL than those from the control group $(f(G)=0.05)$. With that we can confirm protective role of $\mathrm{A}$ allele in this polymorphism for developing an inflammatory process. Frequency of the genotypes was $\mathrm{f}(\mathrm{A} / \mathrm{A})=0.5$; $f(A / G)=0 ; f(G / G)=0.2$ and $p<0.05(p=0.0461)$ witch shows that there is an equilibrium (Tables 9 and 10). Frequency of the genotypes was $\mathrm{f}(\mathrm{A} / \mathrm{A})=0.9 ; \mathrm{f}(\mathrm{A} / \mathrm{G})=0.1 ; \mathrm{f}(\mathrm{G} / \mathrm{G})=0.0$ and $\mathrm{p}>0.05 \quad(\mathrm{p}=0.5988)$ witch shows that there is no equilibrium (Table 10).

\begin{tabular}{|c|c|c|c|c|}
\hline \multirow{2}{*}{$\begin{array}{l}\text { Polymorphism } \\
\text { of MMP-1 detected with restricted enzyme Alul }\end{array}$} & \multirow[b]{2}{*}{ Number } & \multicolumn{2}{|c|}{ Examined groups } & \multirow{2}{*}{ Total } \\
\hline & & Chronic periapical lesions & Control group & \\
\hline \multirow{2}{*}{-/- (homozygotes for absence) } & $\mathrm{N}$ & 2 & 59 & 61 \\
\hline & $\%$ & $5 \%$ & $49.2 \%$ & $43.6 \%$ \\
\hline \multirow{2}{*}{-l+ (homozygotes for absence) } & $\mathrm{N}$ & 19 & 10 & 29 \\
\hline & $\%$ & $47.5 \%$ & $8.3 \%$ & $20.7 \%$ \\
\hline \multirow{2}{*}{-/+ (homozygotes for absence) } & $\mathrm{N}$ & 19 & 51 & 70 \\
\hline & $\%$ & $47.5 \%$ & $42.5 \%$ & $50 \%$ \\
\hline
\end{tabular}

Table 2: Representation of the polymorphism $-16071 \mathrm{G} / 2 \mathrm{G}$ for the gene of MMP-1 detected with restristed enzyme Alul in patients from examined groups.

\begin{tabular}{|c|c|c|c|c|}
\hline \multirow{2}{*}{ Polymorphism of MMP-1 detected with restricted enzyme Kpnl } & \multirow[b]{2}{*}{ Number } & \multicolumn{2}{|c|}{ Examined groups } & \multirow{2}{*}{ Total } \\
\hline & & Chronic periapical lesions & Control group & \\
\hline \multirow{2}{*}{$-/-$ (homozygotes for absence) } & $\mathrm{N}$ & 18 & 109 & 127 \\
\hline & $\%$ & $45 \%$ & $90.8 \%$ & $90.7 \%$ \\
\hline \multirow{2}{*}{ +/+ (homozygotes for absence) } & $\mathrm{N}$ & 9 & I & 9 \\
\hline & $\%$ & $22.5 \%$ & I & $6.4 \%$ \\
\hline \multirow{2}{*}{$-/+($ homozygotes for absence) } & $\mathrm{N}$ & 13 & 11 & 24 \\
\hline & $\%$ & $32.5 \%$ & $9.2 \%$ & $17.1 \%$ \\
\hline
\end{tabular}

Table 3. Representation of the polymorphism $-519 \mathrm{~A} / \mathrm{G}$ for the gene of MMP-1 detected with restristed enzyme Kpnl in patients from examined groups

\begin{tabular}{|c|c|c|c|c|}
\hline \multirow{2}{*}{ Polymorphism of MMP-1 detected with restricted enzyme Kpnl } & \multirow{2}{*}{ Number } & \multicolumn{2}{|c|}{ Examined groups } & \multirow{2}{*}{ Tota } \\
\hline & & Chronic periapical lesions & Control group & \\
\hline \multirow{2}{*}{-/- (homozygotes for absence) } & $\mathrm{N}$ & 18 & 109 & 127 \\
\hline & $\%$ & $45 \%$ & $90.8 \%$ & $90.7 \%$ \\
\hline \multirow{2}{*}{ +/+ (homozygotes for absence) } & $\mathrm{N}$ & 9 & 1 & 9 \\
\hline & $\%$ & $22.5 \%$ & 1 & $6.4 \%$ \\
\hline \multirow{2}{*}{-/+ (homozygotes for absence) } & $\mathrm{N}$ & 13 & 11 & 24 \\
\hline & $\%$ & $32.5 \%$ & $9.2 \%$ & $17.1 \%$ \\
\hline
\end{tabular}

Table 4. Representation of the polymorphism -519 A/G for the gene of MMP-1 detected with restristed enzyme Kpnl in patients from examined groups.

\begin{tabular}{|c|c|c|c|c|}
\hline Genotype & $\mathbf{1 G / 1 G}$ & $\mathbf{1 G / 2 G}$ & $\mathbf{2 G / 2 G}$ & Total \\
\hline Number $\mathbf{n}$ & 9 & 7 & 24 & 40 \\
\hline Allel 1G & 18 & 7 & 0 & 25 \\
\hline Allel 2G & 0 & 7 & 48 & $\mathbf{0 . 3 1}$ \\
\hline
\end{tabular}

Table 5. Frequency of the allels in the polymorphism -1607 1G/2G for the gene of MMP-1 detected with restristed enzyme Xmnl in patients with CPL. 


\begin{tabular}{|c|c|c|c|c|c|}
\hline Genotype & $1 \mathrm{G} / 1 \mathrm{G}$ & $1 G / 2 G$ & $2 \mathrm{G} / 2 \mathrm{G}$ & Total & Frequency of the alleles \\
\hline Number $\mathbf{n}$ & 83 & 30 & 7 & 120 & 240 \\
\hline Allel 1G & 166 & 30 & 0 & 196 & 0.82 \\
\hline Allel 2G & 0 & 30 & 14 & 44 & 0.18 \\
\hline Genotype & $1 \mathrm{G} / 1 \mathrm{G}$ & $1 G / 2 G$ & $2 \mathrm{G} / 2 \mathrm{G}$ & Total & Frequency of the alleles \\
\hline Number $\mathbf{n}$ & 83 & 30 & 7 & 120 & 240 \\
\hline Allel 1G & 166 & 30 & 0 & 196 & 0.82 \\
\hline Allel 2G & 0 & 30 & 14 & 44 & 0.18 \\
\hline
\end{tabular}

Table 6. Frequency of the allels in the polymorphism $-16071 \mathrm{G} / 2 \mathrm{G}$ for the gene of MMP-1 detected with restristed enzyme Xmnl in patients from controle group.

\begin{tabular}{|c|c|c|c|c|}
\hline Genotype & 1G/1G & $\mathbf{1 G / 2 G}$ & $\mathbf{2 G / 2 G}$ & Total \\
\hline Number $\mathbf{n}$ & 2 & 19 & 19 & 40 \\
\hline Allel 1G & 4 & 19 & 0 & 23 \\
\hline Allel 2G & 0 & 19 & 38 & 50 \\
\hline
\end{tabular}

Table 7. Frequency of the allels in the polymorphism $-16071 \mathrm{G} / 2 \mathrm{G}$ for the gene of MMP-1 detected with restristed enzyme Alul in patients with CPL.

\begin{tabular}{|c|c|c|c|c|}
\hline Genotype & $\mathbf{1 G} / \mathbf{1 G}$ & $\mathbf{1 G / 2 G}$ & $\mathbf{2 G / 2 G}$ & Total \\
\hline Number $\mathbf{n}$ & 59 & 51 & 10 & 120 \\
\hline Allel 1G & 118 & 51 & 0 & 169 \\
\hline Allel 2G & 0 & 51 & 20 & $\mathbf{0 . 7 0}$ \\
\hline
\end{tabular}

Table 8. Frequency of the allels in the polymorphism -1607 1G/2G for the gene of MMP-1 detected with restristed enzyme Alul in patients from controle group.

\begin{tabular}{|c|c|c|c|c|}
\hline Genotype & A/A & A/G & G/G & Total \\
\hline Number $\mathbf{n}$ & 10 & 22 & 8 & 40 \\
\hline Allel A & 20 & 22 & 0 & 42 \\
\hline Allel G & 0 & 2 & 16 & 30 \\
\hline
\end{tabular}

Table 9. Frequency of the allels in the polymorphism $-519 \mathrm{~A} / \mathrm{G}$ for the gene of MMP-1 detected with restristed enzyme Kpnl in patients with CPL.

\begin{tabular}{|c|c|c|c|c|c|}
\hline Genotype & A/A & A/G & G/G & Total \\
\hline Number $\mathbf{n}$ & 59 & 51 & 10 & 120 \\
\hline Allel A & 118 & 51 & 0 & 169 \\
\hline Allel G & 0 & 51 & 20 & $\mathbf{0 . 7 0}$ \\
\hline
\end{tabular}

Table 10. Frequency of the allels in the polymorphism $-519 \mathrm{~A} / \mathrm{G}$ for the gene of MMP-1 detected with restristed enzyme Kpnl in patients from controle group.

\section{Discussion}

MMPs play an important role during periapical pathology development [17], and it has been suggested that the modality of root canal treatment could interfere with MMPs expression [18].

Due to their various roles in bone remodeling, immune responses, caries, and dental development, it is hypothesize that variation in MMPs and TIMP genes may alter the level of bone destruction and remodeling and contribute to the formation of more extensive periapical lesions in teeth affected by deep carious lesions $[19,20]$.

Results in our study indicate that individual genetic predisposition have influence on periapical lesion formation. We can confirm that polymorphism of the gene for MMP-1 contributes for increasing individual frequency of apical tissue destruction as a reaction to deep caries lesion. Our results are in correlation with findings of Rutter et al. [11] in which is show that this polymorphism can have functional consequences because can affect the function of MMP-1, as well as, is polymorphism who is candidate with strong biological significance for developing inflammatory process. Also our result are in correlation with finding of Cao et al. [21] in which genetic variations in promontory region of the gene of MMP-1 have influence on the transcription level and as a results of this, the gen of MMP-1 have crucial role in degradation of connected tissue in periodontis.
Beside this, Itagaki et al. [9], have not detected differences between allele of the gene of MMP-1 and genotypic distribution in healthy Japanese and those with chronic periodontitis. Findings about the detected frequence of $\mathrm{G}$ allel in polymorphs $-519 \mathrm{~A} / \mathrm{G}$ of the gene for MMP-1in our study are in relationship with findings of Oh $\mathrm{H}-\mathrm{S}$ et al. [22], where is observed similar distribution of the genotypes and frequencies of the alleles.

Polymorphism - 1607 1G/2G for the gene MMP-1 detected with restristed enzymes $\mathrm{Xmnl}$ and $A l u l$ is an risck factor for developing chronic periapical lesion. Individuals who are carriers of $2 \mathrm{G} / 2 \mathrm{G}$ genotype and individuals with $1 \mathrm{G} / 2 \mathrm{G}$ genotype ( $2 \mathrm{G}$ carriers) in this polymorphism shows affection for developing chronic periapical lesion. Polymorphism -519 A/G for the gene MMP-1 detected with restristed enzymes $K p n l$ is a risck for developing chronic periapical lesion and individuals who are carriers of $\mathrm{G} / \mathrm{G}$ genotype and individuals with A/G genotype ( $G$ carriers) in this polymorphism shows affection for developing chronic periapical lesion.

\section{Conclusion}

With this study we can identify the genetic factors that are of enormously meaning for establishing the risk profile of the patients who have affection for developing chronic periapical lesions in Macedonian population, and variations in gene alleles of the MMP-1 are markers for monitoring the risk and progression of this inflammatory process. 
Our findings are fundamental for identification of gene polymorphism of MMP-1 in Macedonian population, as a starting point in further investigations of MMPs gene expression, enable to predict the course and development of clinical sign of inflammatory process, indirectly pointed the adequate therapeutic method.

\section{References}

1. Visse R, Nagase H (2003) Matrix metalloproteinases and tissue inhibitors of metallo-proteinases: structure, function and biochemistry. Circ Res 92: 827-839.

2. Hideaki N, Woessner JF (1999) Matrix metalloproteinase. J Biol Chem 274 21491-21494.

3. Parks WC, Mecham RP (1998) Matrix Metalloproteinases. Academic Press: San Diego.

4. Parks WC, Wilson CL, López-Boado YS (2004) Matrix metalloproteinases as modulators of inflammation and innate immunity. Nat Rev Immunol 4: 617-629.

5. Scherer S, de Souza BT, de Paoli J, Brenol CV, Xavier RM, et al. (2010) Matrix metalloproteinase gene polymorphisms in patients with rheumatoid arthritis. Rheumatol Int 30: 369-373.

6. Hill PA, Murphy G, Docherty AJ, Hembry RM, Millican TA, Reynolds JJ, et al (1994) The effects of selective inhibitors of matrix metalloproteinases (MMPs) on bone resorption and the identification of MMPs and TIMP-1 in isolated osteoclasts. J Cell Sci 107: 3055-3064.

7. Guise TA (2009) Breaking down bone: new insight into site-specific mechanisms of breast cancer osteolysis mediated by metalloproteinases. Genes Dev 23 : 2117-2123.

8. Page-McCaw A, Ewald AJ, Werb Z (2007) Matrix metalloproteinases and the regulation of tissue remodeling. Nat Rev Mol Cell Biol 8: 221-23.

9. Itagaki M, Kubota T, Tai H, Shimada Y, Morozumi T (2004) Matrix metalloproteinase-1 and -3 gene promoter polymorphisms in Japanese patients with periodontitis. J Clin Periodontol 31: 764-769.

10. Hyong-Suk O, Ok-Su K, Young-Jun K, Hyun-Ju C (2009) MMP-1 promoter polymorphism in Korean with generalized aggressive Periodontitis. J Korean Acad Periodontol 39: 269-278.
11. Rutter JL, Mitchell TI, Buttici G, Meyers J, Gusella JF, et al. (1998) A single nucleotide polymorphism in the matrix metalloproteinase-1 promoter creates an Ets binding site and augments transcription. Cancer Res 58: 5321-5325.

12. Caiyun Z, Xicheng S, Minhui Z, Song S, Meng L, et al. (2013) Association between MMP1 -1607 1G>2G Polymorphism and Head and Neck Cancer Risk: A Meta-Analysis. PLoS One 8: 56294

13. De Souza AP, Trevilatto PC, Scarel-Caminaga RM, Brito RB, Line SR (2003) MMP-1 promoter polymorphism: association with chronic periodontitis severity in a Brazilian population. J Clin Periodontol 30: 154-158.

14. Dereka X, Mardas N, Chin S, Petrie A, Donos N (2012) A systematic review on the association between genetic predisposition and dental implant biological complicatiopns. Clin Oral Impl Res 23: 775-788.

15. Tsioufis C, Bafakis I, Kasiakogias A, Stefanadis C (2012) The role of matrix metalloproteinases in diabetes mellitus. Curr Top Med Chem 2: 1159-1165.

16. Gemmel NJ, Aniyama S (1996) An efficient method for the extraction of DNA from vertebrate tissues. Ecol and Evol 12: 338-339.

17. Corotti MV, Zambuzzi WF, Paiva KB, Menezes R, Pinto LC, et al. (2009) Immunolocalization of matrix metalloproteinases-2 and -9 during apical periodontitis development. Arch Oral Biol 54: 764-771.

18. Paula-Silva FW, da Silva LA, Kapila YL (2010) Matrix metalloproteinase expression in teeth with apical periodontitis is differentially modulated by the modality of root canal treatment. J Endod 36: 231-237.

19. Menezes-Silva R, Khaliq S, Deeley K, Letra A, Vieira AR (2012) Genetic Susceptibility to Periapical Disease: Conditional Contribution of MMP2 and MMP3 Genes to the Development of Periapical Lesions and Healing Response. Jour Endo 38: 604-607.

20. Itagaki T, Honma T, Takahashi I, Echigo S, Sasano Y (2008) Quantitative analysis and localization of mRNA transcripts of type I collagen, osteocalcin, MMP 2, MMP 8, and MMP 13 during bone healing in a rat calvarial experimental defect model. Anat Rec: 1038-1046.

21. Cao Z, Li C, Zhu G (2006) MMP-1 promoter gene polymorphism and susceptibility to chronic periodontitis in a Chinese population. Tissue antigens 68: 38-43.

22. Oh H-S, Kim OS, Kim YJ, Chung HJ (2009) MMP-1 promoter polymorphism in Korean with generalized aggressive periodontitis. J Korean Acad Periodonto 39: $269-278$ 